\title{
Effect on yield, total phenolic, total flavonoid and total isothiocyanate content of two broccoli cultivars (Brassica oleraceae var italica) following the application of a commercial brown seaweed extract (Ascophyllum nodosum)
}

\author{
Theodora Lola-Luz ${ }^{1,3}$, Franck Hennequart ${ }^{2}$ and Michael Gaffney ${ }^{1}$ \\ ${ }^{1}$ Horticulture Development Department, Teagasc, Ashtown Food Research Centre, Ashtown Dublin 15, Ireland \\ ${ }^{2}$ Oilean Glas Teo, Kilcar. Co. Donegal,Ireland \\ ${ }^{3}$ Agrifood Scientific, Dublin 5, Ireland. Expert advice, research management, proposal preparation. \\ dora@agrifoodscientific.eu
}

\begin{abstract}
Field experiments were conducted to evaluate the effect of an unfortified extract, of Ascophyllum nodosum on yield and nutritional quality of two broccoli cultivars ('Ironman' and 'Red Admiral'). Total phenolic, total flavonoid, and total isothiocyanates content were higher in all seaweed treatments compared to the untreated control. In 'Ironman' there was a 2.2 fold increase in total phenolic, 1.5 fold in total flavonoid and 2.6 fold in total isothiocyanates content, in the higher application rate compared to the control. Similarly in 'Red Admiral', there was a 2.3 fold increase in total phenolic, 2.6 fold in total flavonoid and, 2.2 fold in total isothiocyanates content. There was a consistent effect on the increase of total phenolic, total flavonoid and total isothiocyanates content, while there was no yield increase recorded at the lower seaweed application rate. Results suggest that application of seaweed extracts can significantly increase the amount of phytochemicals and improve the nutritional quality of broccoli.
\end{abstract}

Key words: Phenolics, flavonoids, marine algae, horticulture, Brassica crops.

\section{Introduction}

Ascophyllum nodosum (Linnaeus) Le Jolis, is a perennial brown marine alga which is abundant along the coastline of many temperate countries such as Canada, France, Ireland, Iceland, Norway and the United Kingdom (Bozorgi 2012, Kandasamy et al. 2011). It is one of the most widely-researched seaweed species which traditionally has been used as a fertilizer, a soil conditioning agent, animal feed and also as a human nutritional supplement (Craigie 2011). A. nodosum is one of the most important commercial seaweeds and it is sustainably harvested by hand with a knife (Ireland) or by hand cutter rakes (Canada) (Bozorgi 2012). They are used as aqueous extracts or finely chopped powdered algal manures for agricultural and horticultural purposes (Thirumaran et al. 2009, Annicia et al. 2009). In recent years commercial seaweed extracts have been used as fertilisers to enhance seed germination, growth, and yield of many crops (Crouch and Staden 1993, Sivasankari et al. 2006). Depending on the application, they are either supplied as unfortified seaweed extracts or enhanced with amino acids, macronutrients, proteins or growth hormones. These fortified extracts are sometimes tailor made by formulators for use with specific crop requirements (Craigie 2011).

Seaweed extracts are mainly applied to crops as root dips, soil drenches or foliar sprays. They contain most macro and micro nutrients, growth promoting compounds, trace elements, vitamins and amino acids (Zodape et al. 2011). Thus when these compounds are added to the soil or sprayed on plants they have the potential to stimulate growth, improve nutrient uptake, increase root development, and improved tolerance to biotic/abiotic stress (Khan et al. 2009, Craigie 2011). Seaweed extracts have been shown to improve phenolic antioxidant content in spinach. This is due to an increase in the concentration of bioactive molecules in the treated plants including antioxidants (Fan et al. 2011). 
Broccoli (Brassicae oleraceae var Italica) belongs to the family of crucifers and is a vegetable of high antioxidant activity (Sun et al. 2007). These vegetables are available throughout the year and are regularly consumed due to their high nutritional value (Guo and Wang 2011). Cruciferous vegetables are an excellent source of nutraceutical compounds such as phenolics, flavonoids, isothiocyanates, antioxidants, vitamins, and glucosinolates, which are a precursor to a group of isothiocyanates known to be anti-carcinogenic (Jeffery et al. 2003, Yoldas et al. 2008, Finley et al. 2011). Some green broccoli varieties have already been characterised in terms of glucosinolate profiles and phenolic compounds (Rosa 1997, Ferreres et al. 2005). Phytochemicals are bioactive substances of plants that have been associated with the protection of human health against chronic degenerative diseases (Lako et al. 2007). These compounds have been studied extensively for their physiological role in plants, such as stress response, resistance to diseases and ability to increase agronomic performance (Picchi et al. 2012). In addition they represent an important quality parameter because of their positive effect in human health (Picchi et al. 2012). Environmental conditions and agricultural practices can affect phytochemical content in plants (Guo et al. 2011). For example growth conditions and environmental stress have been reported to have a significant effect on glucosinolate content in plants (Ciska et al. 2008). However little information is known about the effect of seaweed extracts on these health promoting compounds and nutritional value of Brassica's.

In this paper we report initial results on the effect of using a cold process seaweed extract, AlgaeGreen ${ }^{\mathrm{TM}}$ to increase the phytochemical content of broccoli (total phenolics, total flavonoids and total isothiocyanates) in two different broccoli cultivars. We also determined the effect of this seaweed extract on the yield of broccoli and assessed the possibility of improving the health benefits of broccoli as an added value for consumers.

\section{Materials and methods}

\section{Plant material and cultivation}

Broccoli seeds were placed in cell trays $(23 \times 23 \times 35 \mathrm{~mm})$ containing potting mix (Shamrock compost) and sown at $1.5 \mathrm{~cm}$ deep. Cell trays were placed in an unheated greenhouse $\left(16-20^{\circ} \mathrm{C}\right)$ and were grown for $7-10$ weeks prior to planting in the field. The experiment was conducted at a site in Kinsealy, Dublin, Ireland. (53 $25 \mathrm{~N}$ Lat $610 \mathrm{~W})$. Soil type was characterised as loam to clay loam belonging to the grey brown podzolic soil group. (Altitude: 28 metres O.D., Slope: $1^{\circ}$. Drainage: Moderately well drained).

For the 2011 trial 'Ironman' (green broccoli) and for 2012 'Red Admiral' (purple sprouting broccoli) seeds were used. 'Ironman' was planted in June 2011 and harvested in September 2011. 'Red Admiral' was planted in October 2011 and harvested in April 2012. Prior to planting, trays were drenched with Dursban for cabbage root fly control and the field was sprayed with Stomp Aqua ${ }^{\mathrm{TM}}$ (Pendamethalin) at the manufacturers recommended rate $\left(2.8 \mathrm{I} \mathrm{ha}^{-1}\right)$. No insecticides or fungicides were applied on either of the two crops. The commercial seaweed extract AlgaeGreen ${ }^{\mathrm{TM}}$ (Oilean Glas Teo Ltd, Kilcar, Co. Donegal, Ireland) was used. The experimental design was randomised complete block with 6 replications. The experimental area was $798 \mathrm{~m}^{2}$. Each experimental plot was $6.8 \mathrm{~m}$ long, distance between the plants was $45 \mathrm{~cm}$ and the distance between the beds was $20 \mathrm{~cm}$. The four treatments were: control (water), AlgaeGreen ${ }^{\mathrm{TM}} 3 \mathrm{I} \mathrm{ha} \mathrm{h}^{-1}, 30 \mathrm{I} \mathrm{ha}^{-1}$, and $300 \mathrm{I} \mathrm{ha} \mathrm{h}^{-1}$. Each experimental plot consisted of 30 plants (26 treatment and 4 buffer plants). Each plot consisted of 2 beds from which only the inner 2 rows between the 2 beds were assessed in order to prevent spray drift. Spray application was conducted with a spray hood when necessary. Seaweed was applied once a month with a calibrated knapsack sprayer. Seaweed plots received $2.8 \mathrm{ml}$ of AlgaeGreen ${ }^{\mathrm{TM}}\left(3 \mathrm{I} \mathrm{ha} \mathrm{h}^{-1}\right), 28.5 \mathrm{ml}\left(30 \mathrm{I} \mathrm{ha}{ }^{-1}\right)$ and $285 \mathrm{ml}\left(300 \mathrm{I} \mathrm{ha}{ }^{-1}\right)$. Each of these application rates were diluted in equivalent water based on the knapsack calibration. In both years fertilisers were applied as per growers standard application requirements (35.4 kg of N, $9.9 \mathrm{~kg}$ of $\mathrm{P}$ and $33.9 \mathrm{~kg}$ of $\mathrm{K}$ for the $798 \mathrm{~m}^{2}$ area). Soil analysis prior to the commencement of the experiment indicated that our soil had a low content in Nitrogen and Potassium, while the concentration in Phosphorus was determined to be medium.

Broccoli heads/florets from all 13 plants per row (26 plants in total) were collected for assessment. All broccoli harvested in each treatment was used to assess total yield. For total phenolics, total flavonoids and total isothiocyanate content analysis broccoli head/florets were subsampled from each replication, immediately after weighing, by randomly choosing three healthy broccoli heads from each plot and subsampling 5 florets in the 'Ironman' and 5 florets of 'Red Admiral' in each plot. Florets were collected 15 days after the last seaweed application and were then placed in Ziplock bags (Sparks) and stored at $-20^{\circ} \mathrm{C}$ and were analysed within two weeks. 


\section{Methanolic sample extraction}

Methanolic extracts of the broccoli floret samples were prepared as follows: broccoli tissue was ground into fine powder with liquid nitrogen, $0.5 \mathrm{~g} \mathrm{FW}$ were placed in a $50 \mathrm{ml}$ tube and $5 \mathrm{ml} 80 \%$ Methanol (Lennox) was added. Tubes were vortexed and left to stand for 20 minutes and were then mixed by inversion and $2 \mathrm{ml}$ was transferred into a clean $2 \mathrm{ml}$ micro-centrifuge tube (Anachem). The tubes were centrifuged at $12000 \mathrm{rpm}$ at $4{ }^{\circ} \mathrm{C}$ for 5 minutes. The supernatant was placed in a clean micro centrifuge tube and stored at $-20^{\circ} \mathrm{C}$ and were analysed within 2 weeks.

\section{Total phenolics}

The total phenolic content (TPC) was analysed using the Folin-Ciocalteu method (Singleton and Rossi 1965). For measurement of TPC, samples were prepared as follows: $150 \mu \mathrm{l}$ methanolic extract, $150 \mu \mathrm{l} 80 \% \mathrm{MeOH}, 150 \mu \mathrm{l}$ Folin-Ciocalteu reagent (Sigma-Aldrich) and $1050 \mu \mathrm{l} 20 \% \mathrm{Na}_{2} \mathrm{CO}_{3}$ (Lennox) were placed in a $2 \mathrm{ml}$ micro centrifuge tube. Tubes were vortexed immediately and placed in the dark for 20 minutes. They were then centrifuged at $13000 \mathrm{rpm}$ at $4{ }^{\circ} \mathrm{C}$ for 3 minutes and the supernatant was transferred to a fresh tube. The absorbance at $725 \mathrm{~nm}$ $\left(A_{725}\right)$ was determined relative to a blank containing $80 \%$ aqueous methanol instead of the extract. The concentration was determined from a calibration curve using gallic acid as a standard. The results were expressed as gallic acid equivalents (GAE mg $100 \mathrm{~g}^{-1}$ fresh weigh (FW)) per $100 \mathrm{~g}$ FW.

\section{Total flavonoids}

Total flavonoid content (TFC) of fresh broccoli methanolic extracts was spectrophotometrically determined by the aluminium chloride method using a method modified from Zhuang (1992). Briefly, $150 \mu l$ methanolic extract, prepared as above, was mixed with $600 \mu \mathrm{H}_{2} \mathrm{O}$ and $45 \mu \mathrm{l} 5 \% \mathrm{NaNO}_{2}$ (Sigma-Aldrich). The solution was incubated for 5 minutes at room temperature and then $45 \mu \mathrm{l} 10 \% \mathrm{AlCl}_{3}$ (Sigma-Aldrich) were added and incubated for one more minute. Finally $300 \mu \mathrm{l} \mathrm{M} \mathrm{NaOH}$ (Sigma-Aldrich) and $300 \mu \mathrm{H}_{2} \mathrm{O}$ were added. Absorbance at $510 \mathrm{~nm}\left(\mathrm{~A}_{510}\right)$ was determined from methanolic extracts. Total flavonoid concentration was determined from a standard curve using catechin as a standard. Results were expressed as catechin equivalents (CE mg $100 \mathrm{~g}^{-1} \mathrm{FW}$ ).

\section{Total isothiocyanates}

Total isothiocyanates was determined by UV spectrophotometry according the mehod developed by Zhang et al. (1992). Isothiocyanates from each sample were extracted as follows: $0.05 \mathrm{~g} \mathrm{FW}$ of ground freeze tissue was placed into a $30 \mathrm{ml}$ tube (Anachem), $500 \mu \mathrm{l}$ phosphate buffer $100 \mathrm{mM}\left(\mathrm{K}_{2} \mathrm{PO}_{4^{\prime}} \mathrm{pH}\right.$ 8, Sigma-Aldrich) was added and vortexed gently to re-suspend. The solution was incubated for 20 minutes at $20{ }^{\circ} \mathrm{C}$, vortexed gently to re-suspend and placed at room temperature for 1 hour, to allow autolysis. After this, $0.13 \mathrm{~g} \mathrm{MgSO}_{4}$ (Sigma-Aldrich), $0.02 \mathrm{~g}$ $\mathrm{NaCl}$ (Sigma-Aldrich) and $3 \mathrm{ml}$ ethyl acetate (Sigma-Aldrich) were added to each tube and vortexed gently to resuspend. The solution was then placed on a shaker at $2000 \mathrm{rpm}$ for 15 minutes and centrifuged at $3000 \mathrm{rpm}$ at 4 ${ }^{\circ} \mathrm{C}$ for 10 minutes. The supernatant was removed and placed in a clean $30 \mathrm{ml}$ tube, and placed in a Techne sample concentrator $\left(\mathrm{N}_{2}\right.$ dryer) to remove the solvent. The procedure was repeated twice by adding $2 \mathrm{ml}$ of ethyl acetate to the pellet each time, vortexed gently and placed on shaker and centrifuged as described above. Once the solvent evaporated, the extract was re-suspended in $6 \mathrm{ml} \mathrm{HPLC}$ grade methanol (Sigma-Aldrich) and placed on a shaker at $2000 \mathrm{rpm}$ for 10 minutes. Samples were then filtered through a $0.2 \mu \mathrm{M}$ Millipore filter into a $30 \mathrm{ml}$ tube and stored at $-80{ }^{\circ} \mathrm{C}$. Samples for spectrophotometric measurement were prepared as follows: $900 \mu \mathrm{l}$ of $\mathrm{K}_{2} \mathrm{PO}_{4}$ pH 8 (Sigma-Aldrich), $900 \mu \mathrm{l}$ Methanol (Sigma-Aldrich), $100 \mu \mathrm{l}$ of the sample and $100 \mu \mathrm{l}$ of Benzene-1,2-dithiol $(80 \mathrm{mM}$ prepared in methanol, Sigma Aldrich) were added in a $2 \mathrm{ml}$ micro centrifuge tube and gently mixed. Samples were incubated at $60^{\circ} \mathrm{C}$ for 90 minutes and allowed to cool to room temperature. Absorbance from 6 replicates was measured at $365 \mathrm{~nm}\left(\mathrm{~A}_{365}\right)$. Quantification was measured by means of a calibration curve using sulforaphane (Sigma-Aldrich) as a standard (2.8-280 $\mu \mathrm{M})$. Total isothiocyanate content was expressed as micromoles sulforaphane equivalents per gram of FW.

\section{Yield}

After maturation broccoli heads and florets from the middle two rows of each treatment were harvested ( 26 heads for 'Ironman' and all 'Red Admiral' florets from the 26 experimental plants) and weights were recorded. Sampling in the two varieties was different as 'Ironman' develops in one main head while 'Red Admiral' develops into many smaller florets. Total yield in kg per plot was calculated. 


\section{Statistical analysis}

All data are expressed as mean \pm standard deviation unless otherwise stated. Data were analysed using ANOVA, Friedman's and Kruskal Wallis test (Minitab 15). A significant difference was considered at the level of $p<0.05$ or $p<0.01$.

\section{Results}

\section{Total phenolics}

Total phenolics are presented in Figure 1 and expressed as GAE mg $100 \mathrm{~g}^{-1} \mathrm{FW}$. Significant differences were found in 'Ironman' (Friedman, df=3, $p<0.008$ ) between all liquid seaweed treatments and the control (Fig. 1a). No differences between the seaweed treatments was recorded. In a smaller trial with 'Ironman', differences although not statistically significant were also recorded in the low application rate (results not presented here).
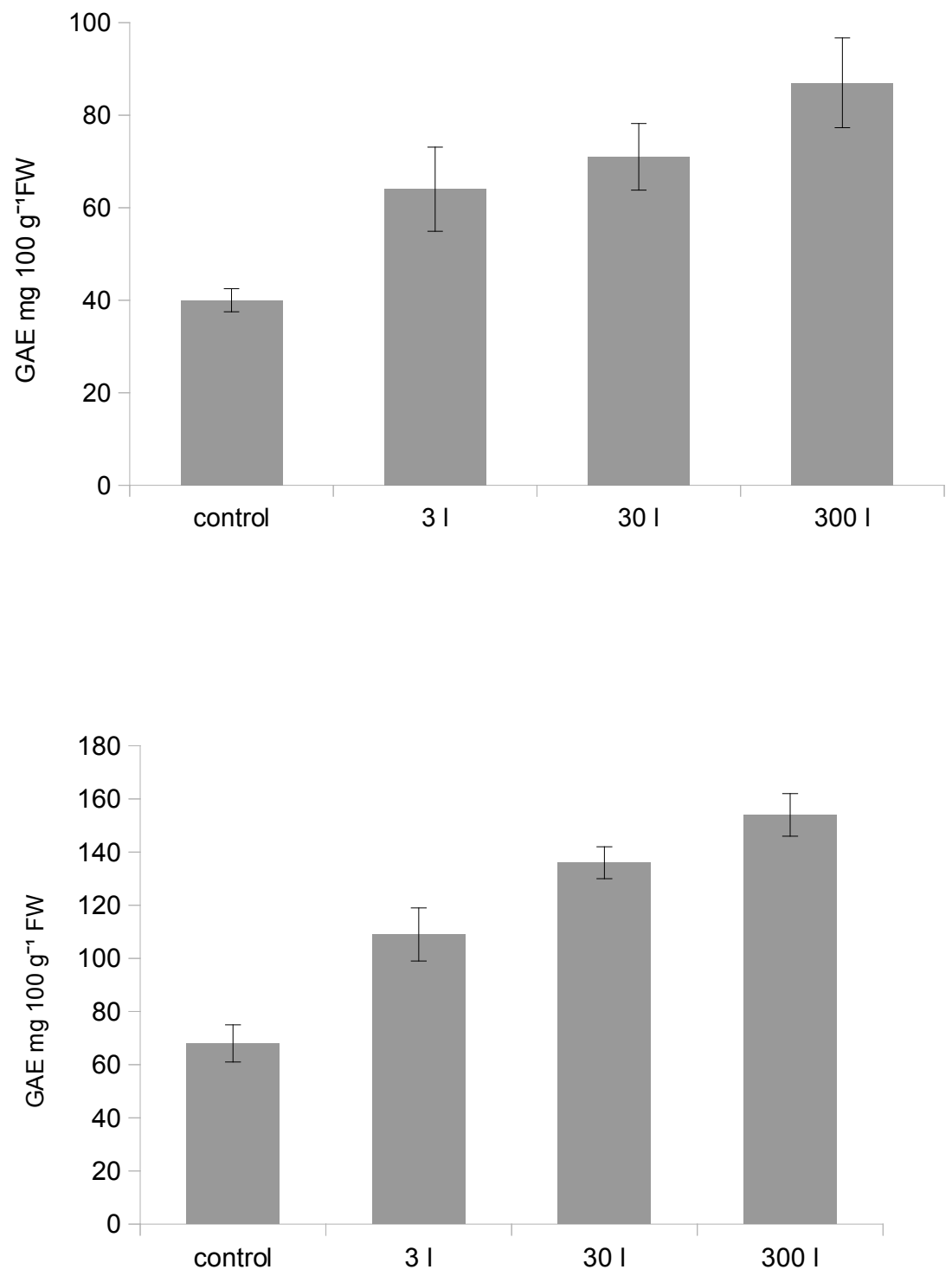

Fig.1. Effect of a commercial liquid seaweed extracts on total phenolic content on two different broccoli cultivars, (a) 'Ironman' and (b) 'Red Admiral'. Treatment plants received three different seaweed application rates of 3, 30 and $300 \mathrm{I} \mathrm{ha}^{-1}$. Bars show the average of replications \pm SD. Results are expressed in Gallic Acid Equivalents (GAE mg $\left.100 \mathrm{~g}^{-1} \mathrm{FW}\right)$. 
In 'Red Admiral' similar results were recorded (Fig. 1b). Significant differences were found between the 3, 300 and 30 I ha ${ }^{-1}$ application rates (Kruskal Wallis, $\mathrm{df}=1, p<0.01$ and $p<0.03$ respectively). A similar trend was recorded in a separate trial with 'Red Admiral' with significant differences between the control and the $3 \mathrm{I} \mathrm{ha-1}$ seaweed treatment (ANOVA, $d f=1, p<0.001$, unpublished results).

\section{Total Flavonoids}

The content of total flavonoids in 'Ironman', following seaweed treatment was higher in comparison to the control (Fig. 2a). No differences were recorded between the different seaweed treatments (Friedman, $d f=2, p<0.108$ ).
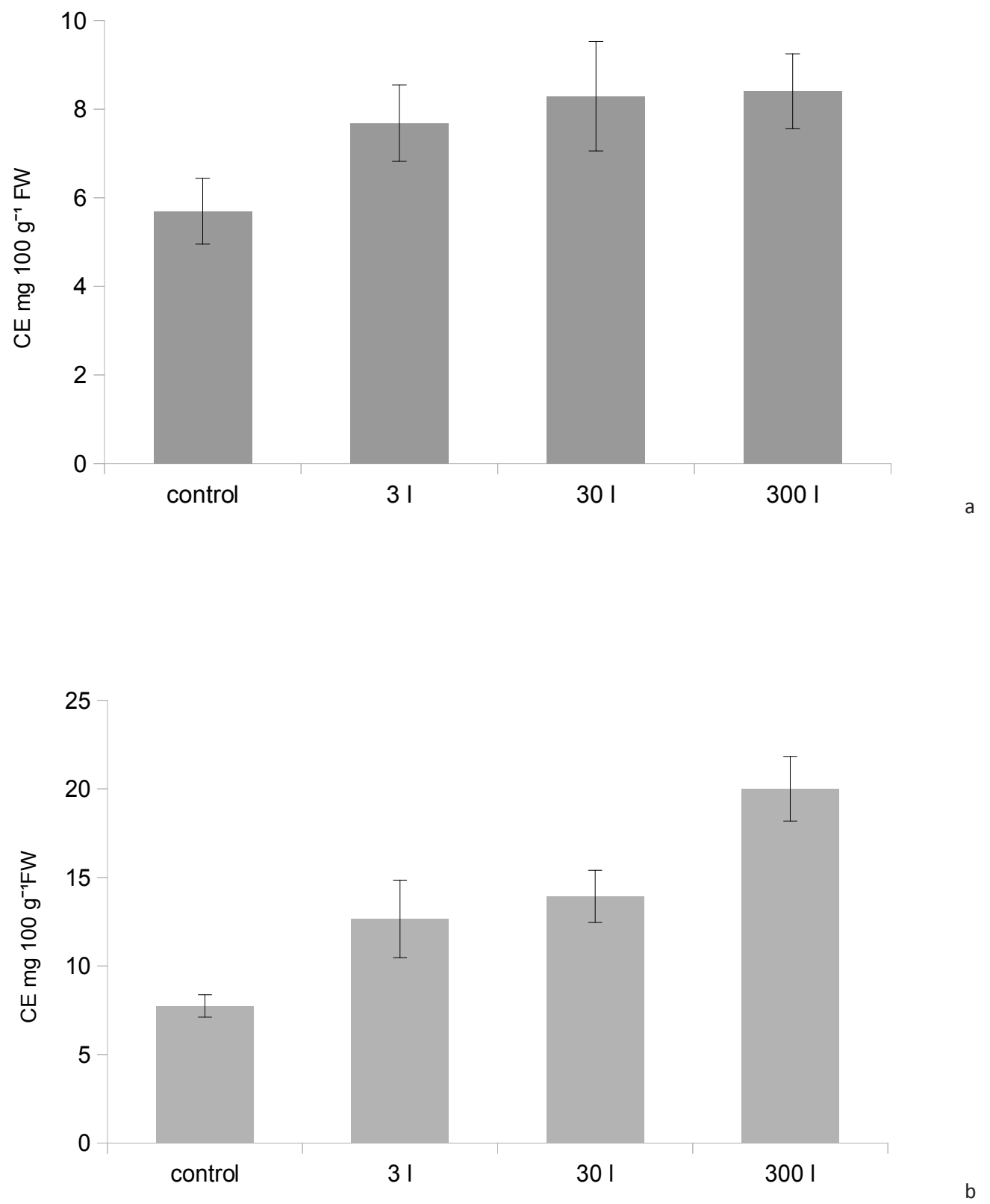

Fig. 2 Effect of a commercial liquid seaweed extracts on total flavonoid content on two different broccoli cultivars, (a) 'Ironman' and (b) 'Red Admiral' . Treatment plants received three different seaweed application rates of 3,30 and $300 ।$ ha $^{-1}$. Bars show the average of 6 replications \pm SD. Results are expressed as CE (catechin) mg $100 \mathrm{~g}^{-1} \mathrm{FW}$. 
For 'Red Admiral' trial, significant differences were found between the control and all seaweed treatments (Fig. $2 b$, Friedman, $d f=2, p<0.006)$, with the $300 \mathrm{I} \mathrm{ha}^{-1}$ treatment exhibiting the highest total flavonoid content. Similar results were observed in TFC in another trial with 'Red Admiral' where only the $3 \mathrm{I} \mathrm{ha-1}$ application rate was used (ANOVA, $\mathrm{df}=1, p<0.001$, unpublished results).

\section{Isothiocyanates}

The application of seaweed extracts had similar effect on the content of isothiocyanates in broccoli in both cultivars (Fig. 3).
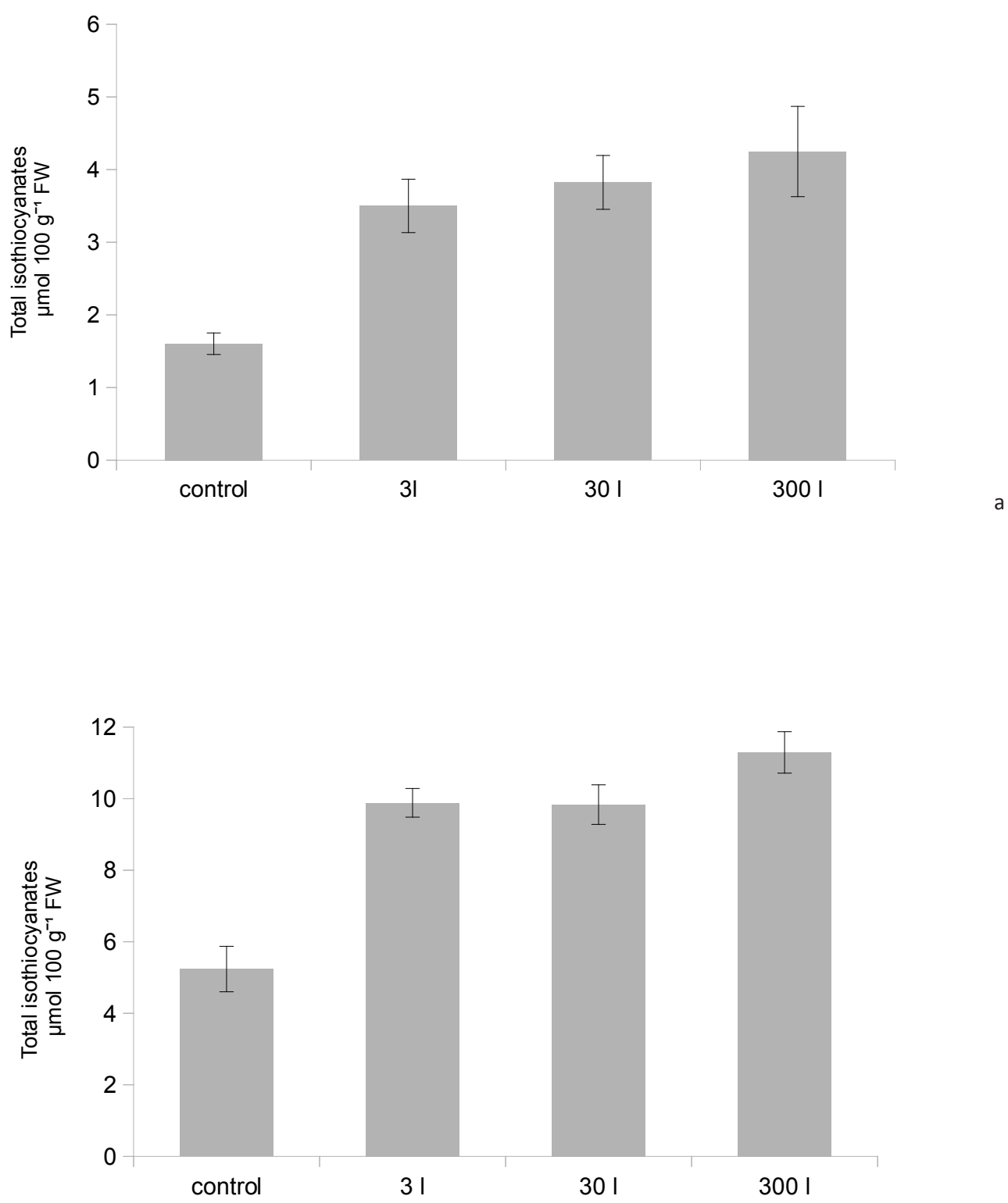

Fig. 3 Effect of a commercial liquid seaweed extracts on total isothiocyanate content on two different broccoli cultivars, (a) 'Ironman' and (b) 'Red Admiral'. Treatment plants received three different seaweed application rates of 3, 30 and $300 \mathrm{I} \mathrm{ha}^{-1}$. Bars show the average of 6 replications \pm SD. Results are expressed as sulforaphane equivalents $\mu \mathrm{mol} \mathrm{g}^{-1} \mathrm{FW}$.

Although there were no significant differences between treatments, the $300 \mathrm{I} \mathrm{ha}{ }^{-1}$ exhibited the highest isothiocyanate content, which was more evident with the 'Red Admiral' cultivar. Liquid seaweed treatments were significantly different from the control (Fig. 3). 


\section{Yield}

There were no significant differences in total yield $\left(\mathrm{kg} \mathrm{ha}^{-1}\right)$ between control and seaweed treatments for either cultivars ('Ironman' : Friedman, $\mathrm{df}=3, p<0.518$; 'Red Admiral' : Friedman, $\mathrm{df}=3, p<0.316$ ). For both trials increased yield was only recorded for the $300 \mathrm{I} \mathrm{ha}^{-1}$ treatment with a $7.2 \%$ increase for 'Ironman' and 31\% increase in 'Red Admiral', although this was not statistically significant (Table 1 ).

Table 1. Effect of seaweed liquid extract Ascophyllum nodosum on yield ( $\mathrm{kg} \mathrm{ha}^{-1}$ ) of two broccoli cultivars (a) Ironman-green broccoli and (b) Red Admiral-purple sprouting broccoli \pm SD ( $n=26$ per replication, total 6 replications).

\begin{tabular}{|c|c|c|c|c|c|c|}
\hline \multirow[b]{2}{*}{ Treatment } & \multicolumn{3}{|c|}{ Ironman } & \multicolumn{3}{|c|}{ Red Admiral } \\
\hline & Total yield & Mean & $\%$ increase* & Total yield & Mean & $\%$ increase* \\
\hline Control & 54.74 & $9.1 \pm 0.5$ & 0 & 16.7 & $2.8 \pm 0.5$ & 0 \\
\hline $3 \mid \mathrm{ha}^{-1}$ & 54.86 & $9.2 \pm 0.2$ & 0.18 & 13.6 & $2.3 \pm 0.3$ & -18.3 \\
\hline $301 \mathrm{ha}^{-1}$ & 53.49 & $8.9 \pm 0.7$ & -1.8 & 14.7 & $2.4 \pm 0.3$ & -12.04 \\
\hline $3001 \mathrm{ha}^{-1}$ & 58.53 & $9.7 \pm 0.3$ & 7.2 & 21.9 & $3.6 \pm 0.4$ & 31.1 \\
\hline
\end{tabular}

* \% increase relative to the control

\section{Discussion}

\section{Total Phenolics}

Seaweed extracts are considered an important source of plant nutrition for sustainable agriculture production (Khan et al. 2009), as they contain various trace elements, vitamins and amino acids, benefiting plant growth and development. The phytochemical content of seaweed treated broccoli plants was investigated in this study. Phytochemicals have been proven to be effective in prevention of certain cancers (Verkerk et al. 1997) and epidemiological studies have shown relationships between vegetable and fruit intake with reducing coronary diseases, certain cancers and diabetes (Wolfe and Liu 2003). The experimental data presented here show that there was an increase in total phenolics in the two broccoli cultivars following seaweed application, with 'Red Admiral' being richer in these phytochemical compounds.

There is limited information on the effect that elicitors such as seaweed extracts have on the phytochemical content of plants. Results from the present study show an increase in the phytochemical content in broccoli plants treated with a seaweed extract, with both varieties having a significant increase in the total phenolic content relative to the control. There was also a constant increase in the total phenolic content as the seaweed rate increased from 3 to $300 \mathrm{I} \mathrm{ha}^{-1}$. This is in agreement with a previous study on cabbage, where similar increases in phytochemical content (phenolics and flavonoids) was also observed (Lola-Luz et al. 2013). This increase was noticeable even at the low application rate of $3 \mathrm{I} \mathrm{ha-1}$. The concentration of total phenolics was almost double in the highest seaweed application rate relative to the control. Broccoli sprouts are naturally rich in phenolic compounds, which are susceptible to stress conditions and can be changed with many elicitors (Guo et al. 2011). The increase in the phenolic content of treated plant can be due to osmotic stress or an increase in plant hormone activities caused by seaweed application. These results are in agreement with Fan et al. (2011), who also reported an increase in total phenolic content when applying a seaweed extract on spinach. In another study on broccoli, sprouts treated with sucrose and mannitol, the latter being a component of seaweed extracts, was also found to be significantly higher in phenolics (Guo et al. 2011).

\section{Total flavonoids and isothiocyanate content}

In addition, increase in the flavonoid and isothiocyanate content in the two broccoli varieties sprayed with a seaweed extract was also measured. There was a consistent increase in these compounds in both experiments. This is in agreement with Fan et al. (2011) who reported a 1.5 times increase in flavonoid content in spinach treated with a different $A$. nodosum extract. They concluded that the increase in total flavonoids was due to an increase in the 
biosynthesis mediated by chalcone isomerase. In the present study, the increase in flavonoid and isothiocyanate content in seaweed treated plants in 'Red Admiral' was almost twice as high from the control. This probably due to the presence of polyphenolics pigments and the higher concentration in antioxidants, vitamins and anthocyanins than in 'Ironman'. In a similar study, it was concluded that biofertilisers (50\% Azotobacter chrococcum and 50\% Bacillus megaterium), increased the amount of total phenolics and flavonoids compared to treatments receiving chemical fertilisers (Naguib et al. 2012). Prior and Cao (2000) indicated that factors such as maturity, cultivars but also other environmental factors like sunlight exposure may influence the phytochemical concentration. This is further supported by another study by Reilly et al. (2013) who concluded that levels of total phenolics, flavonoids and glucosinolates are higher in purple sprouting than green broccoli types.

\section{Total Yield}

In the experiments described here, foliar application of a commercial cold process seaweed, $A$. nodosum did not increase the total yield of broccoli, unless sprayed at the highest concentration rate of $(300 \mathrm{I} \mathrm{ha-1})$. Although from a scientific point of view this is an interesting concentration to test, from a growers perspective it would probably not be economically viable. There are a number of studies indicating that application of seaweed extracts increases yield in a variety of crops. Most of these studies have indicated an increase in yield even at low seaweed application rates between $2-5$ I ha-1. Shehata et al. (2011) found that spraying of celeriac plants with seaweed extracts increased yield in treated plants compared to the control. The liquid seaweed extract used in the Shehata et al. (2011) study, was a mixture of three different species and was also enriched with NPK and plant hormones. Similar results with increased yield were obtained with a pure extract of $A$. nodosum when sprayed on aubergine plants (Bozorgi 2012) however this extract was not fortified with additional macronutrients. Crouch and Staden (1993) also report an increase in growth of tomato when plants were sprayed with seaweed extract derived from Ecklonia maxima. These results are contrary to our findings, as we were not able to find any significant effect on yield at low seaweed application rates $(3 \mathrm{l} \mathrm{ha-1})$. The only significant increase was recorded at the rather high application rate of $300 \mathrm{I} \mathrm{ha}^{-1}$ hence this is the only effective rate but economically not applicable. This is also confirmed by another trial on cabbage where no significant increase in yield was recorded (Lola-Luz et al. 2013). Heckman (1995) also found no significant effect on cabbage yield when using the biostimulants ROOTS (containing a mixture of seaweed, LISA Corp., New Haven, Corm.) and ESSENTIAL (A. nodosum), Growth products, White Plains, NY) at low application rates. In addition to seaweed extracts these products also contain humic acids, vitamins, proteins and carbohydrates. It is possible that such varied results can be due to the different seaweed products used as well as the addition of macro and micro nutrients. Although the chemistry of the bioactive compounds and the mechanism of action of the compounds that impart this increase are largely unknown it is speculated that this may be related to a number of polysaccharides present in seaweed extracts (Khan et al. 2009, Klarzynski et al. 2003). In our study the application of a cold process seaweed extract increased the phytochemical levels in broccoli plants. The enhanced accumulation of phenolic compounds may be related to an increased activity of phenylalanine ammonia lyase (PAL) and peroxidases (PO) enzymes which cause an increase in the available phenolic free pool (Jayaraman et al. 2011). It is well documented that increase in phytochemical compounds can be affected by many factors such as light, water, $\mathrm{CO}_{2}$, methyl jasmonate, abiotic stress factors such as water deprivation (Guo et al. 2011). More research is needed to elucidate the action mechanisms of seaweed extracts and the elicited physiological responses on plants as well as the interactions between plant/pathogen attack in plants with increased levels of phytochemicals. The advantage of using seaweed extracts is that it may help the plants respond to biotic and abiotic stress better, besides promoting plant growth (Jayaraman et al. 2011). The prolonged application of seaweed extract can significantly increase the amount of total phenolics, flavonoids and isothiocyanates. This indicates that these extracts represent a feasible tool to obtain plant foods with enhanced qualitative and quantitative levels of health promoting compounds. These results widen the potential of the use of seaweed extracts in horticulture, especially in light of the recent shift towards organic agriculture and the increased public concern on the use of pesticides and demand by the consumers of safer food. The results presented here demonstrate that inclusion of seaweed extracts in crop management practices can significantly improve the nutritional quality of the treated food and may be a cost effective tool to enhance the health qualities of brassica crops and mitigate the need for time consuming and costly breeding programmes in the production of vegetables with increased health qualities.

\section{Acknowledgments}

The research was financially supported by IRCSET and OGT (IRCSET Enterprise postdoctoral fellowship scheme). Thanks to Leo Finn and Christopher Roberts an all technical stuff for their assistance with the trials. Special thanks to Dr. Laura Alvarez for providing training for isothiocyanate analysis. 


\section{References}

Annicia, Q, Yunque, A.H., Yunque, D.A., Tibubos, K. \& Critchley. A.T. 2009 Use of Acadian marine plant extract powder from Ascophyllum nodosum in tissues culture of Kappaphycus varieties. Journal of Applied Phycology 21: 633-639.

Bozorgi. H.R. 2012. Effects of foliar spraying with marine plant Ascophyllum nodosum extract and nano iron chelate fertiliser on fruit yield and several attributes of eggplant (Solanum melongela I.). ARPN Journal of Agricultural and Biological Sciences 7: 357-362.

Ciska, E., Honke, J. \& Kozlowska, H. 2008. Effect of light conditions on the contents of glucosinolates in germinating seeds of white mustard, re radish, white radish, and rapeseed. Journal of Agricultural and Food Chemistry, 56: 9087-9093.

Craigie, J.S. 2011 Seaweed extract stimuli in plant science and agriculture. Journal of Applied Phycology 23: 371-393.

Crouch, I. \& van Staden, J. 1993. Effect of seaweed concentrate from Ecklonia maxima (osbeck) Papenfuss on Meloidogyne incognita infestation on tomato. Journal of Applied Phycology 5: 37-43.

Fan, D., Hodges, M., Zhang, J., Kirby, C.W., Ji, X., Locke, J.S., Critchley, B. \& Prithiviraj. A.T. 2011. Commercial extract of the brown seaweed Ascophyllum nodosum enhances phenolic antioxidant content of spinach (Spinacia oleracea I.) which protects caenorhabditis elegans against oxidative and thermal stress. Food Chemistry 124: 195 - 202

Ferreres, F., Valentao, P., Lorach, R., Pinheiro, C., Cardoso, U., Pereira, J.A., Sousa, R.M., Seabra, C. \& Andrade, P.B. 2005. Phenolic compounds in external leaves of tronchuda cabbage (Brassica oleracea I. var. costata dc ). Journal of Agricultural and Food Chemistry 53: 2901-2907.

Finley, J.W., Kong, N.A., Hintze, E.H., Jeffery, K.J., Ji, L.L. \& Lei, X.G. 2011 Antioxidants in foods: State of the science important to the food industry. Journal of Agricultural and Food Chemistry 59: 6837-6846.

Guo, G., Yuan, R. \& Wang, Q. 2011. Effect of sucrose and mannitol on accumulation of health promoting compounds and the activity of metabolic enzymes in broccoli sprouts. Scientia Horticulturae 128: 159-165.

Heckman, J.R. 1995. Evaluating phosphorus fertilisation and commercial biostimulants for producing cabbage. HortTechnology 5: 298-300.

Jayaraman, J., Norrie, J. \& Punja. Z. 2011. Commercial extract from the brown seaweed Ascophyllum nodosum reduces fungal diseases in greenhouse cucumber. Journal of Applied Phycology 23: 353-361.

Jeffery, E.H., Brown, A.F., Kurilich, A.C., Keck, A.S., Matusheski, N., Klein, B.P. \& Juvik. J.A. 2003.Variation in content of bioactive components in broccoli. Journal of Food Composition and Analysis 16: 323-330.

Kandasamy, S., Fan, D., Sangha, J.S., Khan, W., Evans, F., Critchley, A.T. \& Prithiviraj, B. 2011. Tasco: a product of Ascophyllum nodosum, imparts thermal stress tolerance in Caenorhabditis elegans. Marine Drugs 9: 2256-2282.

Khan, W., Rayirath, U.P., Subramanian, S., Jithesh, M.N., Rayorath, P., Hodges, D.M., Critchley, A.T., Craigie, J.D., Norrie, J. \& Prithiviraj, B. 2009. Seaweed extracts as biostimulants of plant growth and development. Journal of Plant Growth Regulation 28: 386-399.

Klarzynski, O., Descamps, V., Plesse, B., Jean-Claude, Y., Kloareg, B. \& Fritig. B. 2003. Sulfated fucan oligosaccharides elicit defense responses in tobacco and local and systemic resistance against tobacco mosaic virus. Molecular Plant Microbe Interactions 16:115-122.

Lako, J., Trenerry, V., Wahlqvist, M., Wattanapenpaiboon, N., Sotheeswaran, S. \& Premier, R. 2007. Phytochemical flavonols, carotenoids and the antioxidant properties of a wide selection of Fijian fruit, vegetables and other readily available foods. Food Chemistry 101: 1727-1741.

Lola-Luz, T., Hennequart, F. \& Gaffney, M. 2013. Enhancement of phenolic and flavonoid compounds in cabbage (Brassica oleraceae) following application of commercial seaweed extracts of the brown seaweed, (Ascophyllum nodosum). Agricultural and Food Science 22: 288-295

Naguib, M., El-Baz, F., Salama, Z., Hanaa, A.H.F., \& Gaafar, A.A 2012. Enhancement of phenolics, flavonoids and glucosinolates of broccoli (Brassica oleracea, var. Italica) as antioxidants in response to organic and bio-organic fertilizers. Journal of the Saudi Society of Agricultural Sciences 11: 135-142.

Picchi, V., Migliori, C., Scalzi, R., Campanelli, G., Ferrari, V., \& Di Cesare, L.F. 2012. Phytochemical content in organic and conventionally grown Italian cauliflower. Food Chemistry 130: 501-509.

Prior, R.L. \& Cao, G. 2000. Antioxidant phytochemicals in fruit and vegetables: diet and health implications. Horticultural Science 35: 588-592.

Reilly, K., Finn, L., Rai, K.D., Brunton, N., Sorensen, J.C. \& Gaffney, M. 2013. Potential of cultivar and crop management to affect phytochemical content in winter-grown sprouting broccoli (Brassica oleracea L. var. Italica). Journal of the Science of Food and Agriculture 94:322-330

Rosa, E.A.S. 1997. Glucosinolates from flower buds of portuguese brassica crops. Phytochemistry 44: 1415-1419.

Shehata, S.M., Abdel-Azem, H.S., El-Yazied, A.A \& El-Gizawy, A.M. 2011. Effect of foliar spraying with amino acids and seaweed extract on growth chemical constitutes, yield and its quality of celeriac plant. European Journal of Scientific Research 58: 257-265.

Singleton, V.L. \& Rossi, J.A. 1965. Colorimetry of total phenolics with phosphomolybdic-phosphotungstic acid reagents. American Journal of Enology and Viticulture 16: 144-158.

Sivasankari, S., Venkatesalu, V., Anantharaj, M. \& Chandrasekaran, M. 2006. Effect of seaweed extracts on the growth and biochemical constituents of Vigna sinensis. Bioresource Technology 97: 1745-1751.

Sun, T., Powers, J.R. \& Tang, J. (2009). Evaluation of the antioxidant activity of asparagus, broccoli and their juices. Food Chemistry 105: 101-106.

Thirumaran, G., Arumugam, M., Arumugam, R. \& Anantharaman, P. 2009. Effect of seaweed liquid fertilizer on growth and pigment concentration of Cyamopsis tetrogonolaba (I) taub. American-Eurasian Journal of Agronomy 2: 50-56. 
Verkerk, R., van der Gaag, M.S., Dekker, M. \& Jongen, W.M.F. 1997. Effects of processing conditions on glucosinolates in cruciferous vegetables. Cancer Letters 114:193-194.

Wolfe, K.W. \& Liu, R.H. 2003. Antoxidant activity of apple peels. Journal of Agricultural and Food Chemistry 51: 609-614.

Yoldas, F., Ceylan, S., Yagmur, B., \& Mordogan, N. 2008. Effect of nitrogen fertilizer on yield quality and nutrient content in broccoli. Journal of Plant Nutrition 31: 1333-1343.

Zhang, Y. S., Cho, C., Posner, G.H. \& Talalay, P. 1992. Spectroscopic quantification of organic isothiocyanates by cyclondensation with vicinal dithiols. Analytical Biochemistry 205: 100-107

Zhuang, L.Y. 1992. Extraction and determination of flavonoid in ginkgo. Chinese Herbal Medicine 23: 122-124.

Zodape, S.T., Gupta, A., Bhandari, S.C., Rawat, U.S., Chaudhary, D.R., Eswaran, K. \& Chikara, J. 2011. Foliar application of seaweed sap as biostimulant for enhancement of yield and quality of tomato (Lycopersicon esculentum mill.). Journal of Scientific and Industrial Research 70: 215-219 